\title{
8. DISTRIBUTION OF NEOGENE AND QUATERNARY PLANKTONIC FORAMINIFERS FROM THE UPPER CONTINENTAL RISE OF THE NEW JERSEY MARGIN (WESTERN NORTH ATLANTIC), DEEP SEA DRILLING PROJECT LEG 93, SITE 604: SEDIMENTARY AND PALEOCEANOGRAPHIC IMPLICATIONS OF THE BIOSTRATIGRAPHY ${ }^{1}$
}

\author{
Michel Moullade, Laboratoire de Micropaléontologie et de Géologie Marines, Université de Nice²
}

\begin{abstract}
During Deep Sea Drilling Project Leg 93, upper Miocene through Quaternary sediments were continuously cored in Hole 604, located on the upper continental rise of the New Jersey transect (western North Atlantic). A detailed biostratigraphic study of these strata has been made using the vertical distribution of planktonic foraminifers. The Quaternary climatic zonation of Ericson and Wollin (1968) has been tentatively delineated and all the Pliocene zones and subzones (sensu Berggren, 1977) have been recognized. The rate of sedimentation was slow during most of the Pliocene but underwent a significant acceleration in the early Pleistocene. Quantitative variations in the distribution of planktonic foraminifers appear to be influenced by various factors, such as hydrodynamic winnowing resulting from the action of bottom currents and surficial thermal conditions caused by climatic changes. Both dissolution intervals and brief increases in the coarser detrital input seem, most of the time, to be correlated with indications of climatic cooling and may correspond to glacial events or cycles. This chapter delineates a precursor stage in the inception of Northern Hemisphere glaciation at $3 \mathrm{Ma}$ and wide-scale Quaternary glacial-interglacial cycles.

Data from a detailed study of Hole 604 are briefly compared with the main sedimentary and microfaunal features of contemporaneous series previously drilled along the east American margin in the northwestern Atlantic. One of the striking observations appears to be the intense redistribution of sediments that affected this region in Neogene-Quaternary times.
\end{abstract}

\section{INTRODUCTION}

Neogene through Quaternary beds were penetrated in six holes at three sites during DSDP Leg 93. Site 604, the subject of this study, is located on the upper continental rise along the New Jersey transect (Figs. 1, 2). Hole 604 was drilled at $38^{\circ} 42.79^{\prime} \mathrm{N}, 72^{\circ} 32.95^{\prime} \mathrm{W}$, at a water depth of $2361 \mathrm{~m}$, and penetrated $295 \mathrm{~m}$ of Quaternary, Pliocene, and upper Miocene sediments. Thirtyone rotary cores were taken. Hole 604A was offset about $1.2 \mathrm{~km}$ northwest, in a more proximal position along the transect, at $38^{\circ} 43.08^{\prime} \mathrm{N}, 72^{\circ} 33.64^{\prime} \mathrm{W}$ and at a water depth of $2328 \mathrm{~m}$. This second hole was washed to $250 \mathrm{~m}$, then continuously cored to a sub-bottom depth of $285 \mathrm{~m}$, and finally abandoned after a difficult recovery of four upper Miocene cores.

Quaternary and Neogene sediments drilled at Site 604 are composed predominantly of gray to dark greenish clays and silts, with glauconite-rich sandy intervals, becoming conglomeratic in the lowest (upper Miocene) part (Fig. 3). In Hole 604, 82 samples were investigated in detail for foraminifers. Eight of these samples appeared to be barren, and a few samples were contaminated by reworking of older (exclusively Eocene and/or Miocene) forms. Microfossiliferous samples yielded planktonic and benthic foraminifers, the abundance, preservation, and diversity of which appear to be very variable.

${ }^{1}$ van Hinte, J. E., Wise, S. W., Jr., et al., Init. Repts. DSDP, 93: Washington (U.S. Govt. Printing Office).

Address: Laboratoire de Micropaléontologie et de Géologie Marines, Université de Nice, Parc Valrose, 06034 Nice Cedex, France.

\section{METHODS}

Each of the samples $(\sim 15-20 \mathrm{~g})$ was dried, weighed, boiled in a Calgon solution, and wet-sieved with a minimum mesh size of $63 \mu \mathrm{m}$. The residue was occasionally submitted to ultrasonic treatment. The $>160 \mu \mathrm{m}$ fraction obtained by dry-sieving was divided into two parts. One fraction was considered in the biostratigraphic study, the other was quantitatively analyzed after the residue was microsplit and at least 250 specimens had been counted.

\section{BIOSTRATIGRAPHY}

\section{Planktonic Foraminiferal Zonation}

The vertical distribution of planktonic foraminifers in Cores 1 to 25 of Hole 604 is presented in Figure 4. Cores 26 to 31 (the deepest Miocene part of the hole), characterized by very poor core recovery and low foraminiferal content, are omitted.

From a preliminary examination of planktonic foraminiferal distribution in Hole 604, it appears that the associations are generally dominated by three long-ranging, temperate- to cold-water species, Globorotalia inflata, Globigerina bulloides, and Neogloboquadrina pachyderma. Compared with assemblages from the Atlantic trop$\mathrm{ical} /$ subtropical province, warmer-water species such as keeled globorotaliids, Pulleniatina spp., and Globigerinoides spp. are clearly in a minority in Hole 604. Biostratigraphically these warmer-water forms often constitute the best markers. Their rarity or even, at times, their absence therefore generates serious difficulties for the foraminiferal biostratigraphic analysis of this sequence. It is never certain, for instance, that the lowest and highest occurrences of each species in the hole effectively coincide with the first and last appearance datums of the taxon. I have attempted to subdivide the 


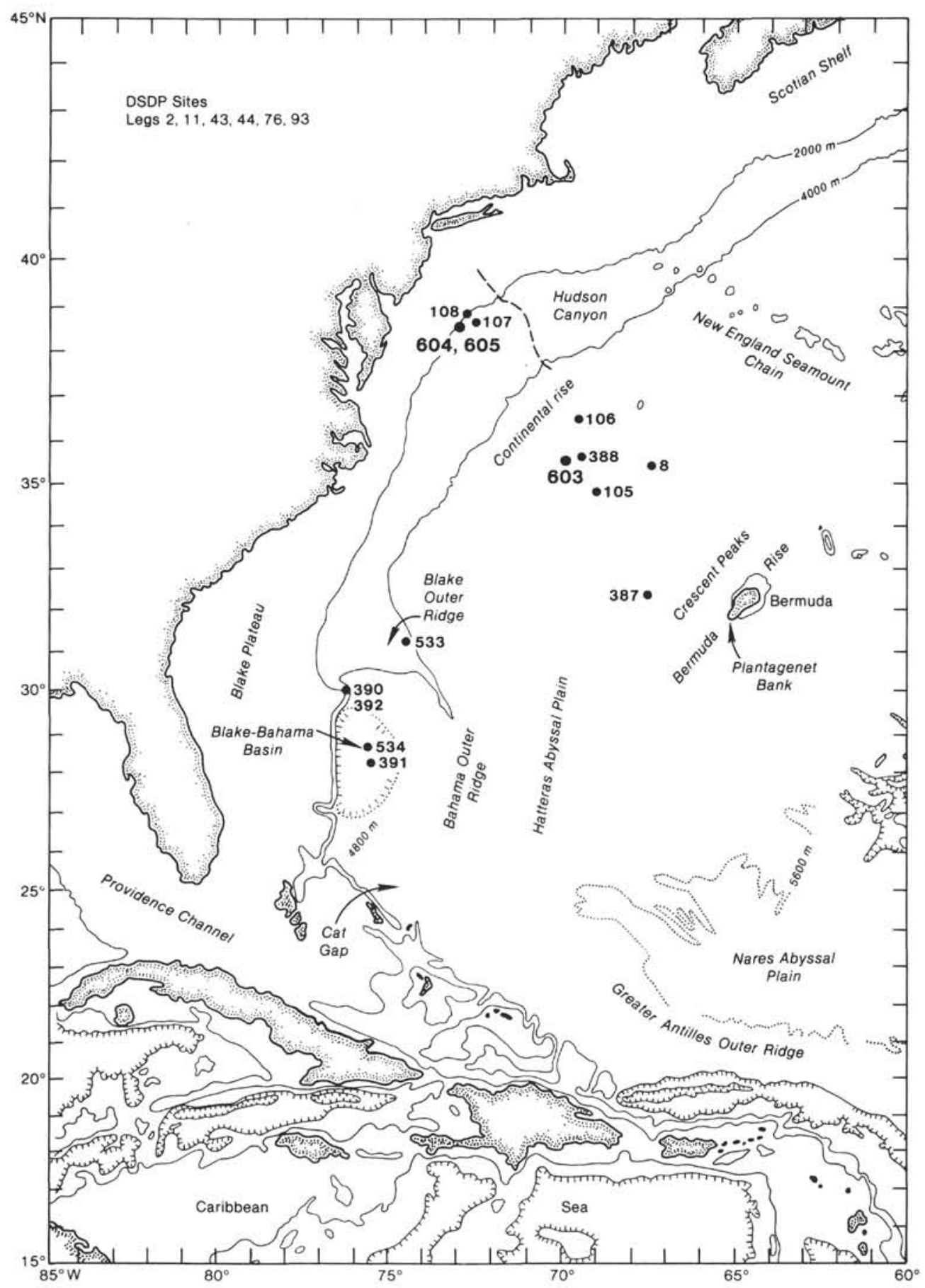

Figure 1. Location of Site 604 relative to other DSDP sites drilled along the east American margin and in the northwestern Atlantic.

Quaternary sequence on the basis of Ericson's zonation, which is climatic rather than truly stratigraphic, and which was defined in the tropical realm by the distribution of warm-water species (Ericson and Wollin, 1968). Its application in higher latitudes, as in Hole 604, is difficult owing to the sporadic occurrence of the main warmwater plexus.

\section{Miocene}

Samples studied from the Miocene part of Hole 604 were often barren or provided only poor foraminiferal as- semblages, diluted by abundant terrigenous material and strongly affected by dissolution. As a result, it is difficult precisely to delineate the Miocene/Pliocene boundary in Hole 604. According to various authors, the first appearance datum (FAD) of Globorotalia margaritae s.s. is supposed to approximate this boundary (for instance, Kennett and Srinivasan, 1983) or to occur in the latest Miocene (Berggren, 1977; Berggren et al., 1983). This marker occurs in great abundance in Sample 604-23-3, 90-94 cm; very rare specimens are found below in Sample $604-24-1,2-4 \mathrm{~cm}$. Unfortunately its phylogenetic an- 


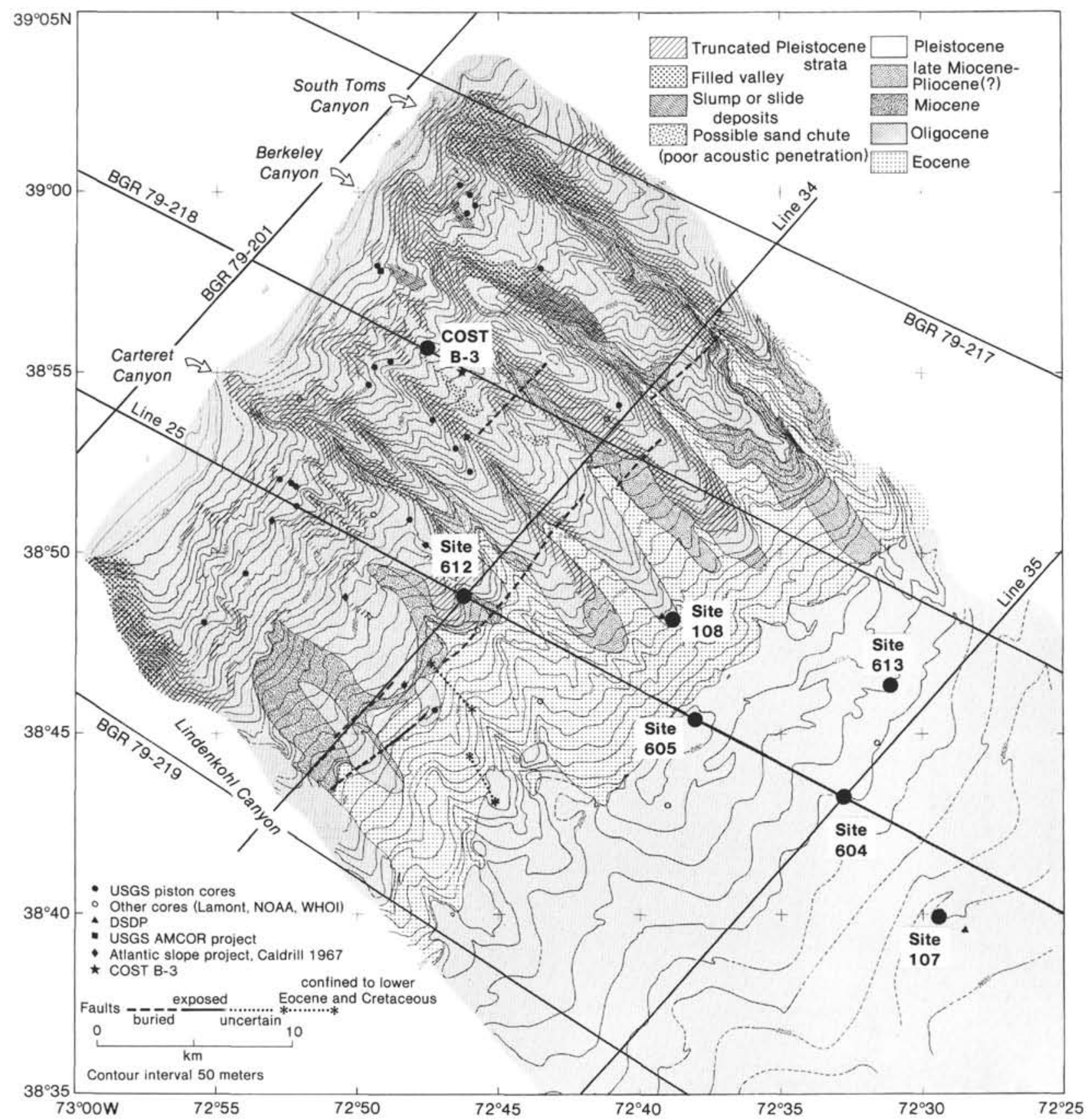

Figure 2. Location of Site 604 relative to neighboring drill sites of the New Jersey Transect.

cestor, G. juanai (junior synonym $=G$. margaritae primitiva) the last appearance datum (LAD) of which also points to the Miocene/Pliocene boundary (Kennett and Srinivasan, 1983), was not found at Site 604. The LAD of Globoquadrina dehiscens may also reach the boundary, but the species may disappear before it through selective dissolution (Berggren, 1982). At this site it becomes extinct in Sample 604-26,CC. I have tentatively placed this boundary between Samples 604-23-3, 90-94 $\mathrm{cm}$ and $604-23-4,90-94 \mathrm{~cm}$, taking into account other arguments as well, including:

1. The distribution in Hole 604 (Fig. 4) of several other species such as Sphaeroidinellopsis paenedehiscens,
Globorotalia merotumida, and G. plesiotumida, all of which more or less straddle or at least approach the boundary (Kennett and Srinivasan, 1983),

2. The highest occurrence of Globigerina praebulloides (the LAD of which indicates the N17/N18 boundary, according to Kennett and Srinivasan, 1983), in Sample 604-23, CC.

Core 24 cannot be not older than Zone N18 (sensu Kennett and Srinivasan, 1983, who accepted it as the youngest Miocene zone), owing to the occurrence of Globorotalia tumida in Sample 604-24,CC. A relatively poor nannofossil and radiolarian record suggests a late Miocene age for Cores $604-25$ to -30 . The presence of 


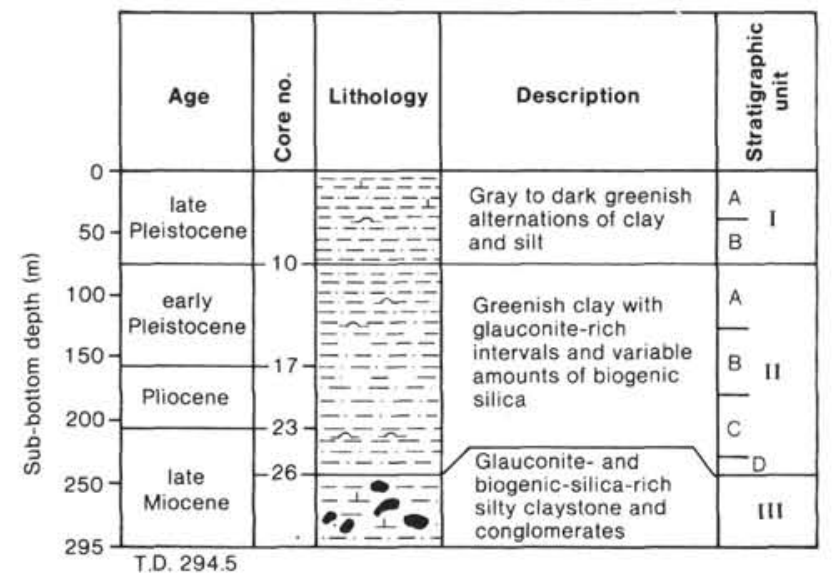

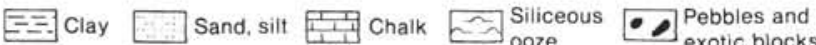

Figure 3. Stratigraphic summary of Site 604 .

middle Miocene beds in the lowest part of Hole 604 is not biostratigraphically documented.

\section{Pliocene}

Pliocene assemblages from Hole 604 are dominated by colder-water species: Globigerina bulloides, Globorotalia puncticulata (which has the same climatic significance in the middle Pliocene as its phylogenetic descendant, $G$. inflata, does in the late Pliocene-Quaternary), and Neogloboquadrina pachyderma, less predominant than during Quaternary, but complemented in the Pliocene by another Neogloboquadrina, N. cf. atlantica, which in Hole 604 first appears in the latest Miocene and becomes extinct in the latest Pliocene. Geographically this species (Berggren, 1982) seems to be restricted to the northeastern Atlantic in rather boreal latitudes. Specimens in Hole 604 show some polymorphism but do not fundamentally differ from the taxon that Berggren described. It also seems to behave like a colder-water species, for it has not been found in the adjoining but more southerly DSDP Sites 603 (Ma'alouleh and Moullade, this volume) and 533 (Moullade, 1983) (latitudes $35^{\circ}$ and $31^{\circ} \mathrm{N}$, respectively).

In the Pliocene interval, as in the Quaternary, warmer-water forms occur only sporadically-for example, Globorotalia tumida and other menardii-form globorotaliids, Globoquadrina altispira, and some keeled globorotaliids in the appropriate stratigraphic intervals (e.g. $G$. margaritae in the lower Pliocene). Their variable distribution may be studied for its paleoclimatic significance, but the irregular occurrence of these marker species does not facilitate biostratigraphic interpretation.

However, all the Pliocene foraminiferal zones, as defined in the middle to low latitudes of the Atlantic by Berggren (1977), can be fairly precisely delineated in Hole 604 . Thus the PL5/PL6 zonal boundary has been placed between Samples 604-18-3, 90-94 cm and 604-18,CC on the basis of the highest occurrence of Globorotalia miocenica. Zone PL3 is separated from Zone PL4 between Sample 604-19-3, 90-94 cm and the barren Sample 604-
$19-4,90-94 \mathrm{~cm}$ by the highest occurrence of Sphaeroidinellopsis seminulina, which should coincide with the lowest occurrence of Sphaeroidinella dehiscens dehiscens. The PL2/PL3 zonal boundary corresponds with the LAD of Globorotalia margaritae in Sample 604-20-2, 90-94 $\mathrm{cm}$. Finally, the boundaries between Subzones PL1b and PL1c, on the one hand, and between Subzones PLla and PL1b on the other hand, are determined, respectively, by the FAD of Globorotalia crassaformis in Sample 604-21-3, 90-94 cm, and the FAD of G. puncticulata in Sample 604-21,CC. Nevertheless, boundaries between Zones PL4 and PL5 and between PL1c and PL2 have not been strictly defined by the vertical range of marker species, for the reasons already noted. They have, instead, been deduced by interpolation using the sediment accumulation rate curve (see Fig. 7, later) assuming an arbitrary linear rate of deposition in the intervals more accurately defined by biostratigraphic markers.

\section{Quaternary}

The zonation of Ericson is usually based on variations of the frequency distribution curve for Globorotalia menardii. However, Briskin and Berggren (1975) have extended this zonation by taking into consideration the G. menardii-G. tumida complex as a whole. Use of this latter criterion in Hole 604 (Fig. 5) allows clear recognition of Ericson's Zone Z (approximately corresponding to the Holocene), which extends from Sample 604-1-1, 90-94 $\mathrm{cm}$ up to the top of Core 1.

Deeper in the hole, the sporadic occurrence of rare specimens of $G$. tumida and very rare $G$. ungulata suggest that:

1. Zone P, the oldest predominantly "warm" Quaternary interval, should begin with Sample 604-16,CC and ought to be extended at least up to Sample 604-15,CC (additional arguments which justify placement of the Pliocene/Quaternary boundary in Core 17 and more precise delineation of the top of Zone $\mathrm{P}$ will be developed below), and

2. Samples 604-11-3, 90-94 cm, 604-9,CC, and 6049-1, 90-94 cm (also taking into account their stratigraphic position) must belong to one of the "warmer" zones ( $\mathrm{R}$ or T, probably) of the middle part of the Quaternary.

We must refine this preliminary zonal scheme based on variations in the distribution of the $G$. menardii-G. tumida complex only; this group appears to be too poorly represented at the latitude of Hole 604 to be of real significance. Consequently Figure 5 also shows (1) variations in the frequency distribution curves of Globigerinoides ruber and $G$. trilobus, two species which are known to prefer warmer water (Bé, 1977); (2) variations in the distribution of Neogloboquadrina pachyderma, a coldwater species. Figure 6 shows evidence derived from several planktonic foraminiferal datum levels observed in Hole 604 (Fig. 6) and already calibrated (Moullade, 1983) for DSDP Site 533, located in a more favorable (subtropical) environment: Neogloboquadrina humerosa LAD, Globorotalia tosaensis LAD, Globigerinoides ruber f. rosea FAD, Pulleniatina finalis FAD, Sphaeroidinella dehiscens (sharp decrease in abundance). 
Combining all these criteria, I propose, in Figures 4 to 6, a subdivision of the Quaternary sequence cored at Hole 604 using approximate equivalents of Ericson's zones.

In this chapter I have not determined the Pliocene/ Quaternary boundary only by seemsAD of Globorotalia truncatulinoides. For the climatic reasons mentioned earlier, this temperate to subtropical species (Bé, 1977) occurs only sporadically in Hole 604. In shore-based investigations, I observed its lowest occurrence in Sample $604-17-1,90-94 \mathrm{~cm}$. In addition, the final "warm" event of the Pliocene seems to correspond better to an interval ending with Sample 604-17-3, 90-94 cm, which still contains some specimens of $G$. tumida and is marked by a clear decrease in Neogloboquadrina pachyderma; Sample 604-17-2, 90-94 cm, in contrast, is devoid of any specimen of the G. tumida-G. menardii complex, contains rare Globigerinoides ruber, and is characterized by a sharp and significant increase in $N$. pachyderma. I have, therefore, placed the Pliocene/Quaternary boundary between Sections 2 and 3 of Core 17. The first Quaternary cold interval, located below Zone $\mathrm{P}$ and above the last Pliocene Zone PL6, was not labelled by Ericson and will be named here "Zone O". It would reasonably correspond in Hole 604 with the upper part of Core 17.

\section{Sedimentary Implications}

Establishing a fairly precise biostratigraphic framework allowed me better to discern significant variations in the sediment accumulation rate during Neogene-Quaternary times at Site 604 .

Data begin with the first point determined with relative accuracy in the Miocene sequence, that is, the FAD of Globorotalia margaritae ( $=5.2 \mathrm{Ma}$ according to various authors), at a sub-bottom depth of $218 \mathrm{~m}$ in Hole 604. Knowing both age and sub-bottom depth of the zonal boundaries (cf. Berggren, 1977; Berggren et al., 1983) or of the climatozones (Briskin and Berggren, 1975; Moullade, 1983), it proved possible to establish the curve shown in Figure 7 (which does not take into account the effects of compaction on the sediment accumulation rates).

After the starting point $(5.2 \mathrm{Ma})$ five principal periods can be distinguished, corresponding to different rates of sediment accumulation:

1. Latest Miocene and Zone PL1a (earliest Pliocene) (duration, $0.6 \mathrm{Ma}$ ); the sediment accumulation rate appears to be moderate, averaging $30 \mathrm{~m} / \mathrm{Ma}$;

2. Largest part of the Pliocene, from Zone PL1b through Zone PL5 (2.4 Ma); a slow rate of $14.6 \mathrm{~m} / \mathrm{Ma}$;

3. Zone PL6 (final Pliocene) and Zone "O" (earliest Quaternary) $(0.46 \mathrm{Ma})$; intermediate rate again, of $37 \mathrm{~m} /$ $\mathrm{Ma}$;

4. Early Quaternary (Zones $P$ to R) $(0.5 \mathrm{Ma})$; a very fast rate of $156 \mathrm{~m} / \mathrm{Ma}$;

5. Late Quaternary (Zones $\mathrm{S}$ to $\mathrm{Z})(1.25 \mathrm{Ma})$; a rate of $56 \mathrm{~m} / \mathrm{Ma}$ (higher in Zone Z, judging by the shape of the curve).

The most striking feature is thus the marked contrast between the clearly slowing Pliocene sediment accumu- lation rate and the rapid increase in sedimentation during the early Quaternary.

\section{PALEOCLIMATOLOGY AND PALEOCEANOGRAPHY}

\section{Quantitative Analysis of the Foraminiferal Distribution}

Figure 8 shows, for each sample studied in the fraction $>160 \mu \mathrm{m}$ from Hole 604: (1) the percentage of planktonic specimens (of total foraminifers); and (2) the total number of foraminifers, of planktonic specimens, and of benthic specimens per $g$ of dried sample. Figure 9 shows the planktonic species diversity (number of species per sample). The resulting curves show significant oscillations.

The present water depth at Hole $604(2360 \mathrm{~m})$ and the paleobathymetric conclusions drawn from a detailed study of the benthic foraminifers (Blanc-Vernet and Moullade, this volume) point to a constant and at least bathyal depth for this site. For such a bathymetric background, the percentages of planktonic foraminifers are normally higher than those observed here or even much higher than $90 \%$ (Gibson and Buzas, 1973). In this chapter such values occur only:

1. In the topmost part of the hole (at least the first $12 \mathrm{~cm}$ of Core 1 , corresponding to the upper part of the Holocene);

2. With some minor irregularities, during a longer period corresponding to the lower Pleistocene (Zones "O," P, and Q) and the middle/upper Pliocene (Zones PL2 to PL6);

3. Very sporadically, in some short intervals of the lower Pliocene, for instance, in Samples 604-23-1, 90$94 \mathrm{~cm} ; 604-23-3,90-94 \mathrm{~cm}$, and of the upper Miocene (Sample 604-24-1, 90-94 cm).

A careful examination of the foraminiferal content of samples with particularly low percentages of planktonic foraminifers, for example, Samples 604-21-3, 90-94 cm and 604-25-1, 90-94 cm, revealed that many or most of the planktonic specimens showed obvious signs of dissolution. These levels are also frequently characterized by a simultaneous significant decline in the planktonic species diversity (Fig. 9). Benthic specimens may be affected too, and in the most severe cases (barren Samples 604-2-1, 90-94 cm; 604-19-3, 90-94 cm; 604-25-2, 90-94 $\mathrm{cm}$; and $604-25, C C)$, all the foraminifers have been dissolved.

Planktonic foraminifers vary in abundance from a few specimens per $\mathrm{g}$ (in levels where dissolution is well advanced) to several thousands per $\mathrm{g}$; the maximum of $5000 / \mathrm{g}$ is reached at the top of the Holocene. Several peaks corresponding to about $1000 / \mathrm{g}$ are observed deeper in the hole, for instance, in the lowermost Pleistocene and in Sample 604-23-1, 90-94 cm (lower Pliocene).

The quantitative distribution of benthic foraminifers is also frequently irregular. Abundances vary from 1-2 specimens/g to more than 100 ; however, such variations are most often neither synchronous with nor in the same direction as those observed for planktonics. For exam- 


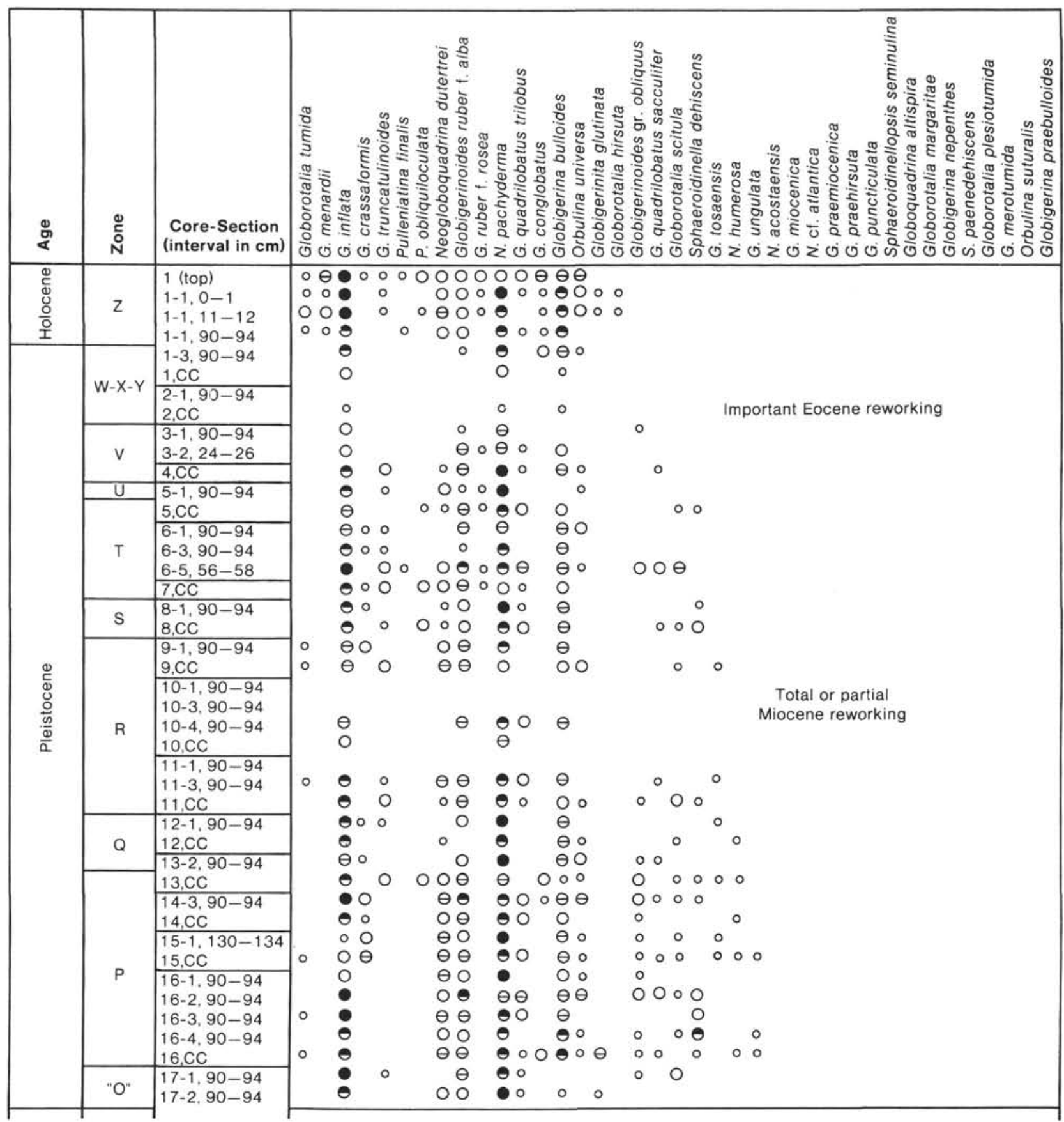

Figure 4. Stratigraphic semiquantitative distribution of planktonic foraminiferal species in samples from Hole 604.

ple, one marked peak with 112 benthics/g sediment is observed in the Holocene, but it does not correspond to the maximum for planktonics; another similar peak (110/ g) seen in Sample 604-21-3, 90-94 cm occurs simultaneously with very low numbers of planktonics.

\section{Paleoclimatic and Paleoceanographic Interpretation}

The paleoenvironmental significance of the quantitative variations in total foraminifers depicted in Figure 8 is better understood when these parameters are closely correlated to the chronologic framework and simultaneously compared with other data, such as quantitative variations at the specific level. Most of these variations seem to reflect paleoclimatic and/or paleoceanographic crises or events and will be reviewed below in ascending chronological order.

\section{Late Miocene}

All parameters based on the quantitative distribution of foraminifers suggest a strong degradation of thermic conditions at the end of the Miocene. Percentages of planktonic foraminifers and total foraminiferal abundance, fell abruptly, except for a brief remission in Sample 604-24-1, 90-94 cm. The worst conditions appear in 


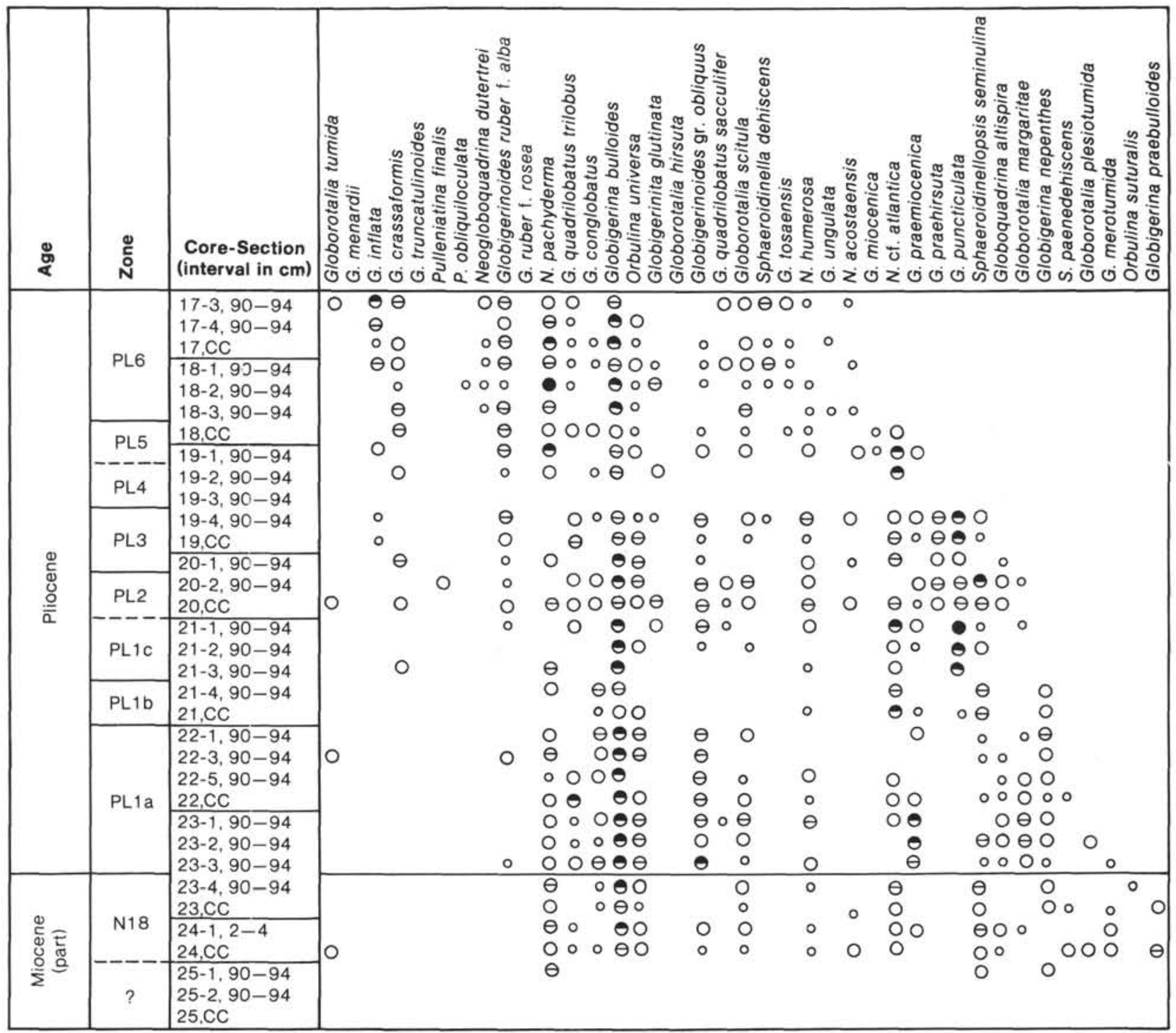

Figure 4 (continued).

Core 25: microfaunal diversity and abundance drop severely in Sample 604-25-1, 90-94 cm, and Samples 604$25-2,90-94 \mathrm{~cm}$ and $604-25, \mathrm{CC}$ are barren. The rarity or even absence of biostratigraphically significant foraminifers at these levels prevent us from dating this late Miocene event with great precision. It is definitely not younger than 5.2 Ma, and it is Messinian. Simultaneously there are very significant influxes of quartz and glauconite grains in the $>160 \mu \mathrm{m}$ fraction, and a concomitant disappearance of pyrite (Fig. 5).

\section{Early Pliocene}

A remarkable decline in the percentages of planktonic foraminifers, reaching a minimum value of $17.5 \%$ in Sample 604-21-3, 90-94 cm (PL1b/PL1c subzonal boundary, at about $3.9 \mathrm{Ma}$ ) and accompanied by a significant differential planktonic dissolution, can also be interpreted as a repercussion of some thermic process (glacial in origin) in the upper water layers. Benthics show a simultaneous abundance peak of 110 specimens $/ \mathrm{g}$.

Inversely, the sudden increase in planktonic foraminiferal abundance (peak of 800 specimens/g) in Sample 604-23-1, 90-94 cm probably corresponds to a productivity high which had no repercussions among benthics and was linked with better thermic conditions. This event occurred at approximately $4.8 \mathrm{Ma}$, near the base of the Pliocene.

\section{Late/Middle Pliocene}

A sudden crisis is reflected in Sample 604-19-3, 90-94 cm (PL3/PL4 zonal boundary), which is barren of foraminifers. Calculating by interpolation, I would date this event (which may be a repercussion of some glacial episode) at approximately 3.0 Ma. 


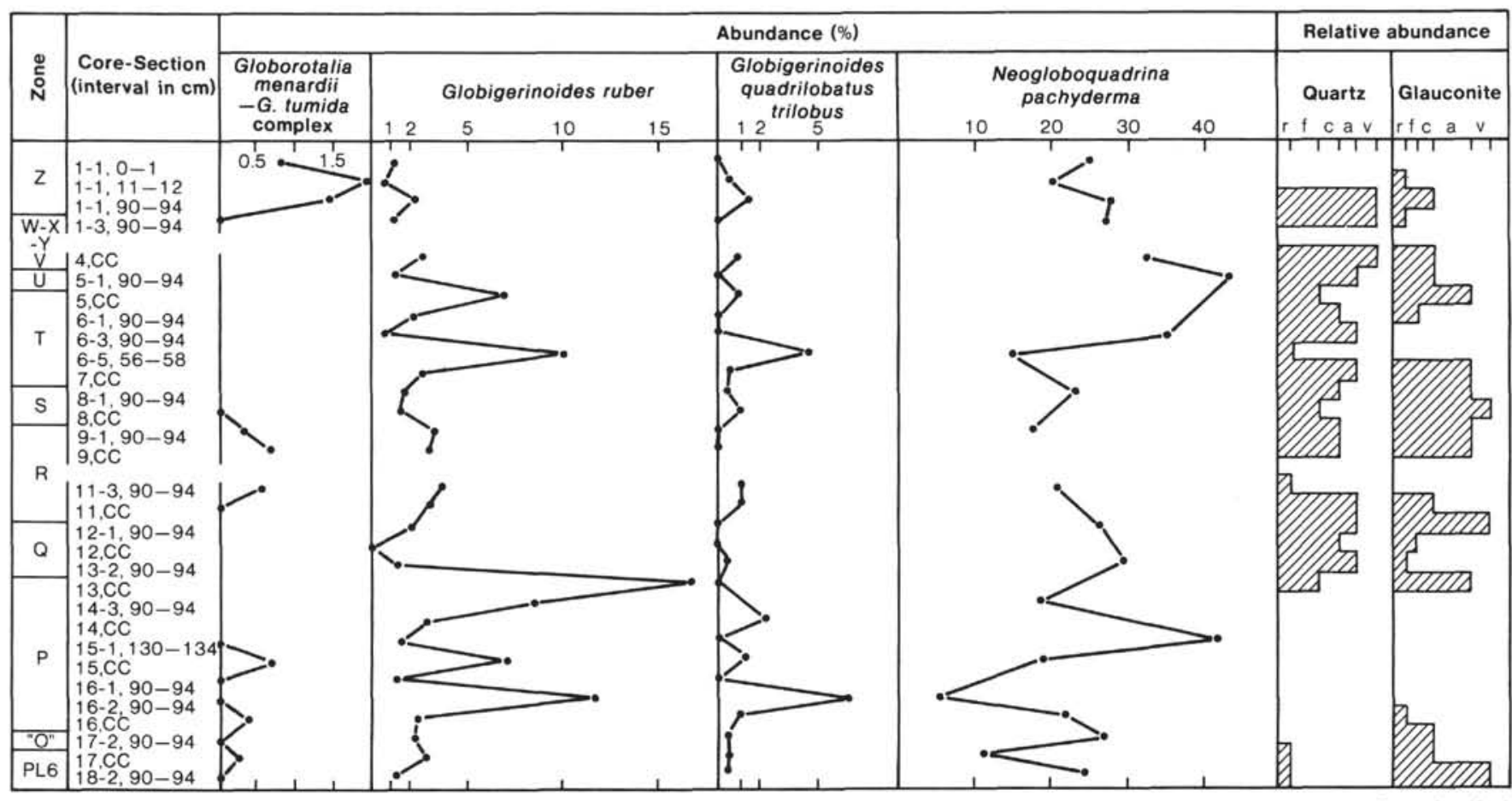

$r=$ Rare, $f=$ Few $c=$ Common, $a=$ Abundant, $v=$ Very abundant

Figure 5. Quantitative distribution of selected planktonic foraminiferal species and semiquantitative distribution of mineralogical components in the $>160 \mu \mathrm{m}$ size fraction from latest Pliocene and Quaternary samples of Hole 604 . Relative abundance of quartz and glauconite estimated by visual inspection of the $>160 \mu$ m residues. In scale, $\mathrm{r}=$ rare, $\mathrm{f}=\mathrm{few}, \mathrm{c}=$ common, $\mathrm{a}=$ abundant, $\mathrm{v}=$ very abundant.

\section{Pleistocene Zones P, Q}

Several events occur during this period, which as a whole is characterized by relatively limited excursions in the percentages of planktonic foraminifers, which are stabilized at values between 80 and $98 \%$, probably denoting smaller effects of calcite dissolution. On the other hand, during Zones P and Q quartz and glauconite debris disappeared from the fraction $>160 \mu \mathrm{m}$; these minerals are replaced in abundance by pyrite (Fig. 5).

There are three well-marked peaks, reaching 300 and 800 specimens $/ g$, in the abundance curve for planktonic foraminifers in this interval (Fig. 8).

The first (the smallest) peak occurs in Sample 604$12-1,90-94 \mathrm{~cm}$, with a simultaneous increase for benthics, in a rather cold climatic context (Zone Q). The curve plotted on Figure 7 shows that the sedimentation rate at this point was rapid, $>150 \mathrm{~m} / \mathrm{Ma}$, excluding concentration of microfossils by sediment starvation. Thus this peak is better explained as resulting from bottomcurrent action (hydrodynamic winnowing) that simultaneously affected both fallen planktonic and originally in situ benthic foraminifers. A detailed analysis, at the specific level, of the benthics (Blanc-Vernet and Moullade, this volume) will enable us to determine the possible influence of another factor, the at least partial enrichment of the benthic microfauna by redeposited allochthonous forms.

Two other more pronounced peaks, more than 700 and more than 800 specimens/g, respectively, affect the planktonic abundance curve in Samples 604-15,CC and 604-16,CC, but the closest samples (604-15-1, 130-134 cm in one case and 604-17-2, 90-94 cm and 604-17,CC in the other) are still characterized by planktonic abundance values reaching at least 600 specimens/g. These two distinct intervals of planktonic foraminiferal proliferation are separated and bracketed by periods in which planktonic rates drop suddenly to less than 100 specimens/ $\mathrm{g}$-only $17 / \mathrm{g}$ in Sample 604-16-2, 90-94 cm, located between the two peaks. In addition, unlike the case of the first peak mentioned, in these last cases the pronounced variations in the planktonic abundance curve do not coincide with those shown in the benthic curve.

These last events occur in a globally "warmer" climatic context (Zone P); calcite dissolution seems to have been minimal with perhaps the minor exception of Sample 604-16-2, 90-94 cm, in which the percentage of planktonics drops abruptly and very briefly from 95 to $76 \%$. These positive peaks in the planktonic abundance curve definitely cannot be interpreted as resulting from sediment starvation, for they also occurred in a period when the rate of sedimentation was very high (Fig. 7). The fact that benthic foraminifers are not simultaneously and similarly affected enables us to exclude current concentration as a possible cause. Therefore, I suggest that productivity, probably enhanced by better thermal conditions, played an important role.

A further confirmation of such a hypothesis is found in planktonic species diversity (Fig. 9), which appears globally higher in the lower than the upper Pleistocene. 


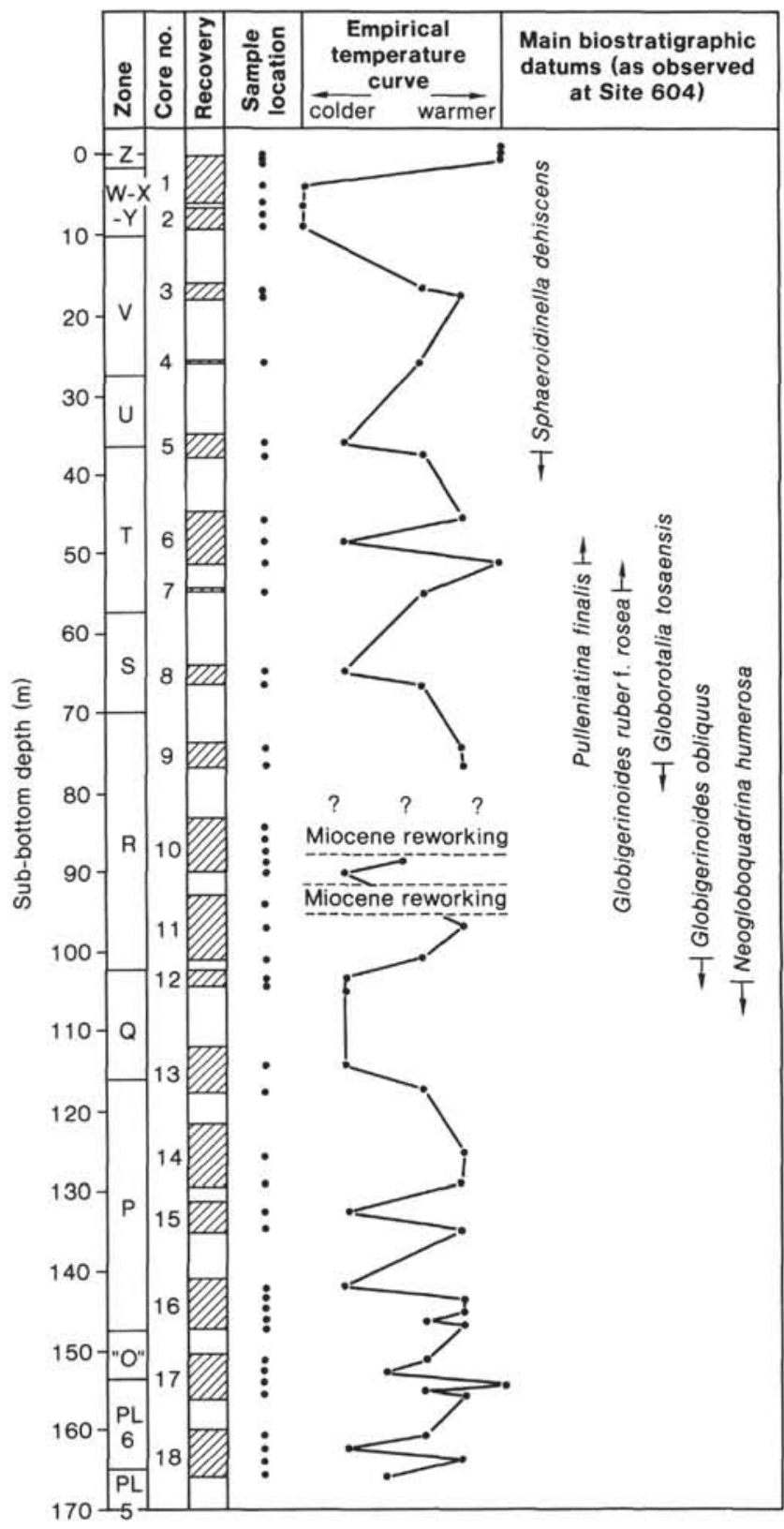

Figure 6. Correlation of the temperature curve, empirically deduced from the quantitative distribution of temperature-sensitive planktonic foraminifers (see Fig. 5), with main planktonic foraminiferal biostratigraphic datums, as observed in late Pliocene and Quaternary samples of Hole 604 (see Fig. 4).

\section{Pleistocene Zone $\mathbf{R}$}

This zone, known to correspond globally to a climatic warming (Ericson and Wollin, 1968; Briskin and Berggren, 1975) is characterized in Hole 604 by a marked increase, with some strong oscillations, in the percentages of planktonic foraminifers (Fig. 8). In addition, significant erosion, leading to reworking of Miocene material, occurs in its middle part. In the upper part of Cores 10 and 11 the in situ Quaternary microfauna totally disappears, and foraminifers in these two intervals are exclusively Miocene. In the lower part of Core 10 the two stocks are mixed, in various proportions. The rarity and low specific diversity of the Quaternary microfauna which coexists with the Miocene reworked forms do not permit a climatic interpretation based on quantitatively significant data. On the whole, samples bracketing this period (i.e., 604-9,CC; 604-11-3, 90-94 cm) or less contaminated samples within its limits $(604-10-4,90-94 \mathrm{~cm}) \mathrm{de}-$ note relatively "warm" climatic conditions; however, the period during which Miocene material was totally reworked may have coincided with a shift to colder conditions. In the tropical realm, the frequency distribution curve of the Globorotalia menardii-G. tumida complex clearly shows several marked oscillations during Zone R (and also T) (Briskin and Berggren, 1975), which probably denote strong, rapid thermic variations during a globally warmer period.

\section{Zones S, T, U, V}

Careful analysis of fluctuations in the various parameters based on the foraminiferal distribution shows that climatic conditions remained globally severe during this period, which does, however, include two episodes thought to be "warmer," Zones T and V. Calcite dissolution certainly occurred at that time, considering the oscillations (between 35 and $80 \%$ ) in the percentages of planktonic foraminifers. Two minor peaks (150/200 specimens/g) for planktonic abundance, situated at the basis of Zone $\mathrm{V}$ and in the middle of Zone T, respectively, do probably record brief periods of slightly better thermic conditions. These peaks are, surprisingly, accompanied by two simultaneous, well-marked ( $70 / 80$ per g) peaks in the benthic curve, although benthic development should not normally be affected by temperature changes that were mostly confined to the surface water masses. This point must be further analyzed by considering the detailed composition of the benthic microfauna (see Blanc-Vernet and Moullade, this volume).

\section{Pleistocene Zones W, X, and Y}

A rapid decline in all the quantitative foraminiferal parameters is observed at this level. Even the benthics are strongly affected. A noticeable accentuation of the process of degradation of temperature is marked by barren samples (thus Sample 604-2-1, 90-94 cm) or by a very poor autochthonous foraminiferal content, dominated by a significant amount of reworked Eocene contaminants (Sample 604-2,CC). Thus it can be assumed that this period was characterized by very strong dissolution processes (shallowing of the CCD) in a colder climatic environment, plus active erosion leading to an increased input from the continent and from the shelf; Figure 5 shows, downward from Sample 604-1-1, 90-94 cm, a large and sudden increase in the quartz and glauconite debris occurring in the mineral part of the $>160 \mu \mathrm{m}$ fraction.

\section{Holocene-Recent}

The extreme proliferation of planktonic foraminifers in the topmost samples of Core 1 is obviously not compatible with normal biocoenotic conditions. Several causes may be suspected: (1) planktonic hyperproductivity, (2) thanatocoenotic environment, (3) concentration by hy- 


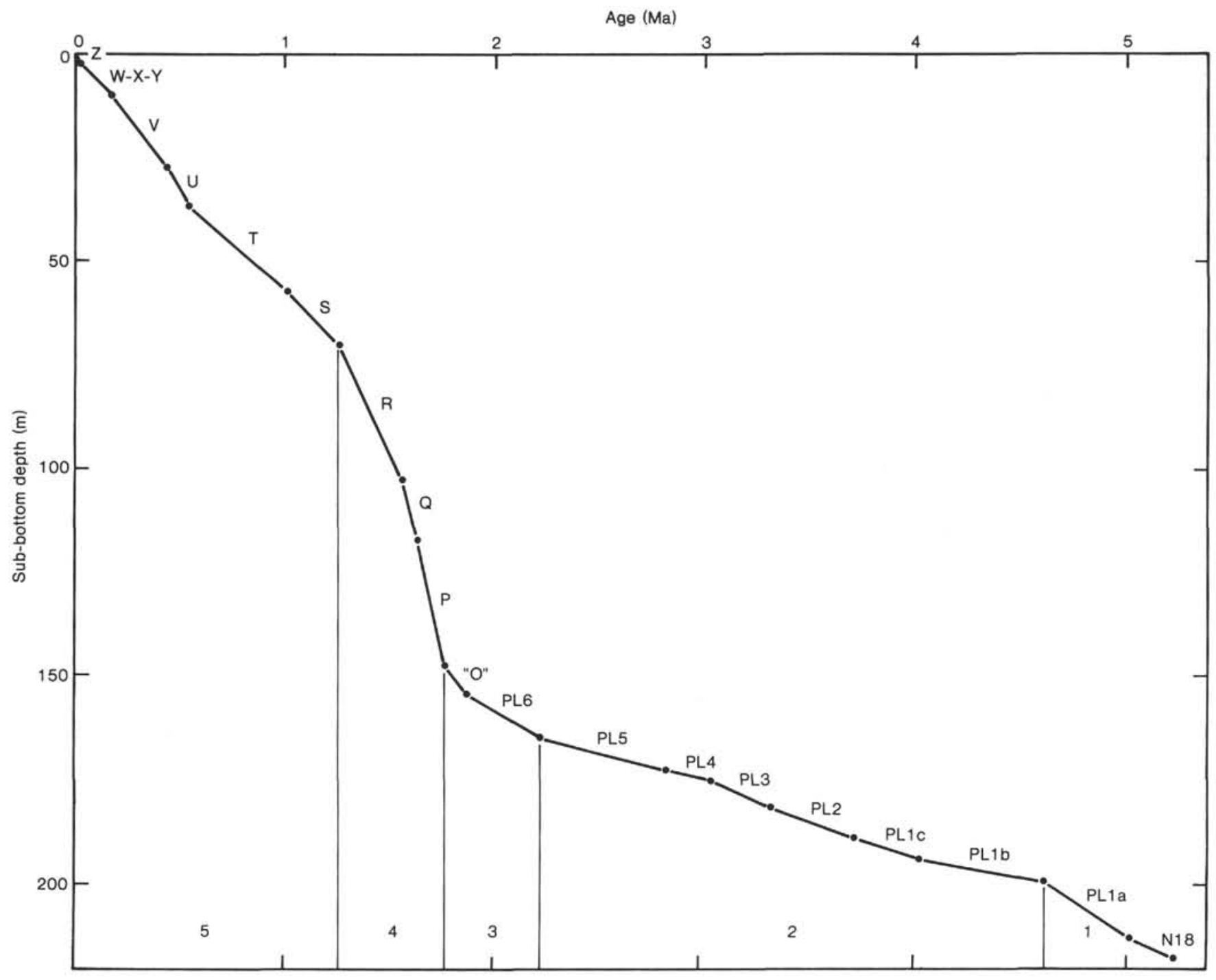

Figure 7. Sediment accumulation rates at Site 604 , based on zonal biostratigraphic boundaries. Numerical calibration of foraminiferal zones is mainly from Berggren (1977), Briskin and Berggren (1975), and Berggren et al. (1983). Numbers refer to text discussion.

drodynamic factors, which would be accentuated in these surficial layers by the greater buoyancy of thin and empty planktonic shells, lighter than sediment and than thickerwalled benthic forms which are also more rapidly filled by sediment after death, and (4) low sedimentation rate (this factor appears unlikely if we consider the steep slope of the Holocene sediment accumulation rate curve in Fig. 7). Surficial concentration because of hyperbuoyancy seems better to explain most of the phenomena, but in this interval we must also take into account the relatively high concentration of benthics $(50$ to $120 / \mathrm{g}$ ), which, as already stated, is not strictly in accordance with that of planktonics. Therefore, possible additional enrichment through hydrodynamic winnowing by bottom currents cannot be dismissed. A detailed analysis of the benthic foraminiferal content (Blanc-Vernet and Moullade, this volume) will also permit a better evaluation of the possible influence of another enriching factor, contamination by allochthonous shallow-water forms transported from the shelf and redeposited at bathyal depths.

\section{COMPARISON OF SITES 603 AND 604 WITH NEARBY DRILL SITES OF THE EAST AMERICAN MARGIN IN THE NORTHWEST ATLANTIC (NEOGENE-QUATERNARY)}

\section{New Jersey Transect}

\section{Slope off New Jersey}

\section{Cost B-3 Well}

This well was drilled in $820 \mathrm{~m}$ of water, on the present upper slope (Fig. 2). Neogene and Quaternary sediments were not cored but the thickness of the Quaternary (150 $\mathrm{m})$, Pliocene $(60 \mathrm{~m})$, and upper Miocene $(120 \mathrm{~m})$ sediments was estimated by seismic correlation. Very similar thicknesses were measured at bathyal Site 604 (this chapter) for the Quaternary and Pliocene. For the COST B-3 well, Poag (1980) suggested a mid/outer shelf paleoenvironment in the late Miocene, followed by an upper slope environment during the Pliocene/Quaternary. 


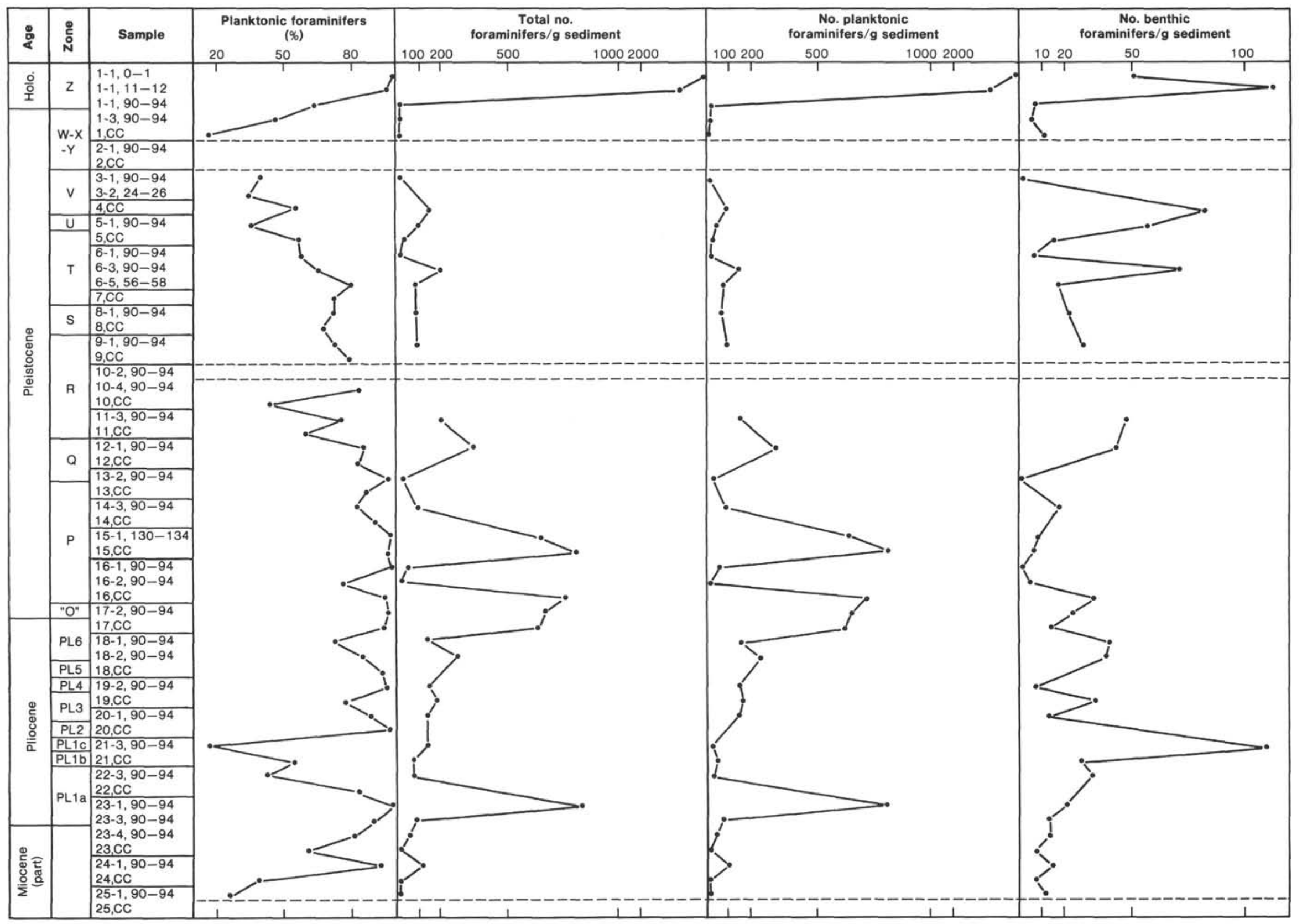

Figure 8. Global quantitative characteristics of samples from Hole 604 (>160 $\mu \mathrm{m}$ fraction). 


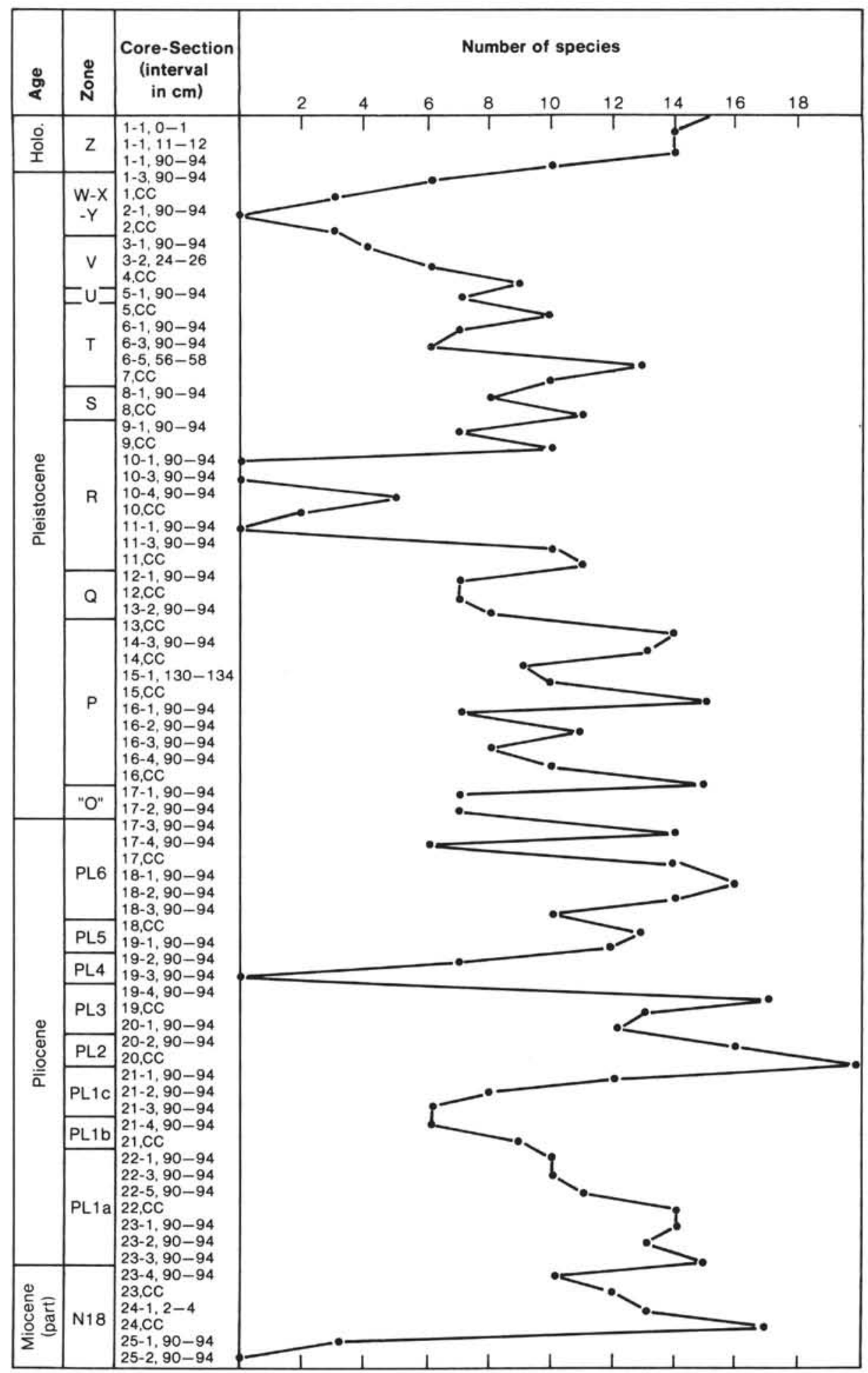

Figure 9. Variations in planktonic foraminiferal species diversity, Hole 604.

\section{DSDP Site 612}

This mid-slope site was drilled in $1400 \mathrm{~m}$ of water, along the New Jersey Transect, in a slightly more proximal position than Site 604 (Fig. 2). In contrast to Site 604, Site 612 has several unconformities corresponding to marked erosional periods. According to Poag, Watts, et al. (pers. comm., 1984) this hole penetrated about 40 $\mathrm{m}$ of upper Pleistocene sediments (maximum duration, $0.44 \mathrm{Ma}$ ) unconformity overlying $50 \mathrm{~m}$ of Pliocene sediments. The available biostratigraphic data do not show whether this Pliocene series is complete or not. Another discontinuity separated the Pliocene from $50 \mathrm{~m}$ of strata attributed to the late Miocene N16-N17 zones and overlying a third discontinuity on lower Oligocene sediments. Glauconite is abundant in this sequence, in which sand 
predominates. In the Quaternary of Site 612, shipboard micropaleontologists found poorly diversified cold-water planktonic foraminiferal assemblages, which is exactly what I found most of the time in contemporaneous levels of Site 604. Recovered benthic foraminifers point to a mid-bathyal paleoenvironment, strongly contaminated during the late Pleistocene by shallow-water forms, such as Elphidium and Nonionella, supposed to have been transported downslope at bathyal depths from neritic environments. Such an interpretation is in total agreement with our interpretation of similar levels of Site 604 (see Blanc-Vernet and Moullade, this volume).

\section{DSDP Site 108}

The site lies on the basal slope in a water depth of $1855 \mathrm{~m}$. Coring started only at $39 \mathrm{~m}$ sub-bottom depth, and only middle Eocene rocks, shown on seismic profiles to be exposed in this area, were recovered (Hollister, Ewing, et al., 1972). These authors noted that a few meters of soft sediments might be present above the point where coring began; that may correspond to a very thin layer of Quaternary and/or Recent muds on the Eocene bedrock. However this may be, it appears that most of the Neogene-Quaternary sequence has been eroded in this area.

\section{Upper Continental Rise off New Jersey}

\section{DSDP Site 605}

This site is located about $6 \mathrm{~km}$ from and is slightly more proximal than Site 604 (Fig. 2), at similar water depth of $2200 \mathrm{~m}$, on the continental rise near the upper rise/lower slope boundary. The 200-m-thick Quaternary series appears to be almost complete (only the lowermost part may be missing) and overlies middle Eocene strata above an erosional discontinuity (site chapter, this volume). Very few cores were taken from the Quaternary, and detailed comparisons with Site 604 are difficult, except for the noticeable increase in thickness.

\section{DSDP Site 613}

This site was drilled in $2330 \mathrm{~m}$ of water on the upper continental rise and slightly to the northeast of Site 604, where seismic profiles showed that the Miocene sands which forced us to abandon Holes 604 and 604A were clearly pinching out. According to Poag, Watts, et al. (pers. comm., 1984) this hole penetrated a Neogene/Quaternary series with at least three discontinuities. First, they encountered $180 \mathrm{~m}$ of mostly upper and middle Pliocene sediments, lying above an erosional contact on $75-80 \mathrm{~m}$ of Pliocene sediments. Above another discontinuity, Pliocene sediments overlie $10 \mathrm{~m}$ of upper Miocene conglomeratic sands, lying in turn over middle Eocene rocks with another erosional surface intervening. For the Quaternary-Neogene deposits, the benthic foraminifers point to a lower bathyal environment. Thus Site 613 differs from nearby Site 604 by more marked erosional processes leading to evident discontinuities and more or less significant hiatuses and, taking the gaps into account, by a slightly more significant sediment accumulation rate for the Pliocene and Quaternary series.

\section{DSDP Site 107}

This site constitutes a more seaward site on the upper continental rise along the New Jersey transect and was drilled in $2570 \mathrm{~m}$ water depth (Fig. 2). The thickness of the Pleistocene at Site 107 may be at least $75-80 \mathrm{~m}$. According to Hollister, Ewing et al. (1972), these Pleistocene sediments yielded predominantly cold-water planktonic foraminiferal assemblages with low diversity and transported and redeposited shallow-water benthics. The authors concluded that the mechanisms involved displacement at bathyal depths of a neritic sediment containing "inner sublittoral microfaunas"; they interpreted the low diversity as evidence of initial "marginal marine conditions." I think that, as at Site 604 , this low diversity might rather be the result of partial dissolution, accentuated when the CCD shallowed during glacial episodes. The authors also noted that reworked Eocene foraminifers were present in the first Pleistocene core of Site 107. At Site 604, reworked Eocene foraminifers were also locally present in the upper Pleistocene sediments (Sample 604-2,CC).

\section{Lower Continental Rise off New Jersey}

\section{DSDP Site 106}

This site was drilled in $4500 \mathrm{~m}$ of water, in a position slightly more landward than and to the north-northeast of Site 603 . Unlike Site 603 , Site 106 penetrated a complete Neogene-Quaternary series.

According to Hollister, Ewing, et al. (1972), Quaternary loose sands and silty clays, including abundant glauconite, were drilled and spot-cored to $350 \mathrm{~m}$ sub-bottom depth. This differs considerably from conditions found at Site 603 , where most of the Quaternary was missing through erosion. According to Poag (1972), Quaternary sediments from Site 106 contained planktonic foraminiferal assemblages dominated by "cool-temperate" forms such as Neogloboquadrina pachyderma and Globigerina bulloides and benthic assemblages characterized by numerous redeposited neritic forms, such as Elphidium and Nonionella. Except for the much greater thickness of the section, these sedimentary and microfaunal features appear to be very similar to those found in the Quaternary sequence of Site 604, which is located relatively far from Site 106, at much shallower water depth, on the upper rise.

Pliocene clays $(150 \mathrm{~m})$ were also recognized at Site 106 , overlying $150 \mathrm{~m}$ of upper Miocene sediments. Poag (1972) found in these Miocene-Pliocene sediments planktonic foraminiferal assemblages characterizing the tropical-subtropical realm and visibly affected by dissolution at some levels. No more displaced neritic benthics were observed.

Similar tropical-subtropical features appear to dominate at Site 603 (Ma'alouleh and Moullade, this volume), where the Pliocene is still thicker (at least $350 \mathrm{~m}$.). Here practically all the Quaternary sequence has been eroded and only its lowermost part (essentially Zones "O" and $\mathrm{P}$, in part) is present. It is reasonable to assume that the missing Quaternary beds were initially very similar to 
those deposited at the very near Site 106. As already noted, the Quaternary series of Site 106 looks very similar to the Quaternary of Site 604, except that it is thicker. Thus the apparently sharp climatic contrast which is suggested by a rapid comparison of the microfaunal contents of Sites 603 and 604, must be noticeably reduced when only what is truly comparable is compared, that is, the deduced Quaternary from one site, using the relay offered by Site 106, with the observed Quaternary from the other site. It thus appears that in this area (which comprises Sites 603 and 106), a Pliocene subtropical environment was clearly followed by cool-temperate conditions during the Pleistocene.

\section{DSDP Site 388}

This site was drilled in $4920 \mathrm{~m}$ of water, very close to Site 603 , but was only partially cored in its upper section ( 11 cores for the first $340 \mathrm{~m}$, down to the middle Miocene, with only 3 cores in the Pliocene-Quaternary).

If complete, Pliocene and Quaternary together are not more than $200 \mathrm{~m}$ thick, which strongly contrasts with the much greater thicknesses observed in the neighboring Sites 106 and 603 . The interpretation of the available data (Benson, Sheridan, et al., 1978) points to planktonic foraminiferal assemblages dominated by cold-water species, but the very discontinuous coring already noted may have encountered only glacial episodes. The lithologic facies that have been observed (oozes, clays, and silty clays) also include some coarse sands. This reinforces the hypothesis of a Quaternary sequence possibly dominated in this area by a significant coarse detrital influx. Finally, as observed at Site 603 by Ma'alouleh and Moullade (this volume), the late Miocene planktonic foraminifers at Site 388 also appeared to be strongly dissolved.

\section{DSDP Site 105}

This site is located SE of and not far from Site 603, at a $5245 \mathrm{~m}$ water depth. Quaternary foraminifers were found only in the two upper spot cores; one, superficial, is assigned to the Holocene, the second was taken at $30 \mathrm{~m}$ sub-bottom depth, yielded Globigerina bulloides and Neogloboquadrina pachyderma, and was attributed to the Pleistocene (Hollister, Ewing, et al., 1972). A third deeper core was attributed to the lower Pliocene on the basis of nannofossils (no foraminifers, certainly dissolved). Estimates of respective thicknesses are uncertain because the coring was so intermittent; they suggest a maximum of $40 \mathrm{~m}$ for the Quaternary and at least $60 \mathrm{~m}$ for the Pliocene. This appears to be evidence of a significant reduction in the thickness of the sediments compared with neighboring Sites 106 and 603 .

\section{Abyssal Plain-Western Bermuda Rise (DSDP Site 387)}

Drilled in $5128 \mathrm{~m}$ of water, this site constitutes the most distal borehole along the wide northwest-southeast transect that begins on the continental shelf off New Jersey. Only the top of the first core yielded foraminifers, and nannofossils disappeared below the first $30 \mathrm{~cm}$. Thus this site appears to have been almost constantly under the CCD. Pleistocene clays, dated by radiolarians, have an estimated thickness of at least $40 \mathrm{~m}$.

\section{Blake Outer Ridge}

DSDP sites drilled on the Ridge, which is located more to the south, off South Carolina and Georgia (at a latitude slightly higher than $30^{\circ} \mathrm{N}$ ), provide a transition between the northern sites listed earlier and the more clearly tropical sites of the Caribbean realm.

\section{DSDP Site 533}

Two holes (533 and 533A) were drilled very close together at a water depth of $3200 \mathrm{~m}$; a series composed of Holocene to middle Pliocene hemipelagic clays was continuously cored (Fig. 10) (see also Moullade, 1983). The Quaternary sediments are $150 \mathrm{~m}$ thick, the uppermost Pliocene is highly condensed; in contrast, the sediment accumulation rate was extremely high during the middle Pliocene, Zone PL3 alone reaching a thickness of at least $170 \mathrm{~m}$. Planktonic foraminiferal assemblages (Moullade, 1983) are typically tropical-subtropical, and benthic specimens (Blanc-Vernet, 1983) showed practically no signs of contamination from the shelf. Excellent recovery and richness in significant foraminifers make this section a reference in the subtropical realm for calibrating biostratigraphic datums based on the principal middle-late Pliocene markers and Ericson's Quaternary climatic zonation.

\section{DSDP Sites 102,103 , and 104}

These three sites are also located on the Blake Outer Ridge, near Site 533, but give less complete information because they were spot cored.

The most complete series was observed in Site 102, drilled, like Site 533 , on the crest of the Ridge, whereas Site 103 (southwest flank) and 104 (northeast flank) showed some erosional discontinuities.

Data combined from the three sites (Hollister, Ewing, et al., 1972; Poag, 1972) show that the Pleistocene series is $220 \mathrm{~m}$ thick (Site 102), the Pliocene is $355 \mathrm{~m}$ thick (Site 102: this high value correlates well with the very thick middle Pliocene and thick lower upper Pliocene observed at Site 533), and the upper Miocene is $300 \mathrm{~m}$ thick (Site 103). According to Poag (1972), major erosional processes occurred during the early Pleistocene, particularly on the flanks of the Ridge. Poag did not depict any erosion on the crest; my own observations (Moullade, 1983), based on a high-resolution biostratigraphic analysis of Hole 533, demonstrated an extremely slow rate of sedimentation in the uppermost Pliocene PL6 Zone and the basal Quaternary " $\mathrm{O}$ " Zone, apparently without any hiatus.

\section{CONCLUSIONS}

A quantitative analysis of the planktonic foraminiferal content of DSDP Site 604 , based on a sample spacing of about $40,000 \mathrm{yr}$., and briefly compared with the available information on microfaunal and sedimentary features of the Neogene/Quaternary series drilled at subtropical to temperate latitudes along the east American margin in the northwest Atlantic, allows me to propose 


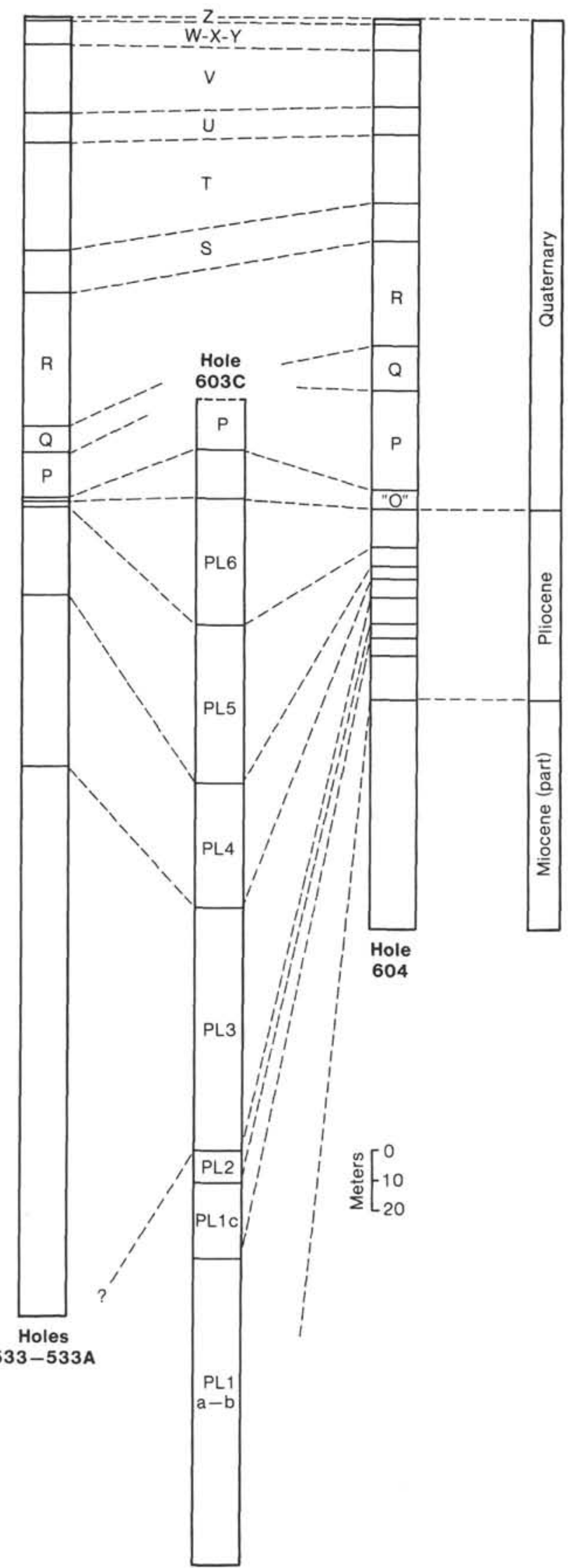

Figure 10. Biostratigraphic correlation among Neogene-Quaternary series from northwest Atlantic Sites 533, 603, and 604. the following sedimentologic, paleoclimatic, and paleoceanographic interpretations:

1. Very significant variations in the thickness of sedimentary deposits occurred throughout (Table 1), with frequent inversions of the process, leading to strong contrasts even between very close sites. Local discontinuities arising from erosion of certain beds or, inversely, impressive increases in thickness reflect the extreme conditions of this diversity. This northwest Atlantic area was affected by an almost constant redeployment of sediments, probably more by the action of bottom currents than as a consequence or irregular influxes. Sediments eroded from one area were accumulated in another area, sometimes very close by. In addition, the sedimentary processes involved in the action of bottom currents may explain most of the frequent faunal enrichments, which were depicted, for instance, in the Site 604 foraminiferal abundance curve.

2. Coarse detrital influxes, marked by an increase in quartz, glauconite, and the like, were regionally more important in the northernmost part of the sector (i.e., New Jersey Transect), which is also characterized by greater contamination by (inner) shelf foraminifers, redeposited at bathyal depths. Chronologically, the detrital input appears to have been more important in late Miocene and middle-late Pleistocene times. Increases in detritic material seemed more or less to have accompanied periods of climatic cooling.

3. The apparently sharp climatic contrast between the two relatively close Sites 603 and 604 is shown to be less sharp when the eroded Quaternary of Site 603 is reconstructed through analysis of the Quaternary sediments at the very near Site 106. In fact, the generalized climatic contrast is more chronological (between the Pliocene on the one hand, and the Quaternary on the other) than geographic. However, in the Quaternary the climatic change appears to be drastic and relatively rapid between sites located at about $30^{\circ} \mathrm{N}$ (i.e., Site 533), containing clearly subtropical planktonic foraminiferal assemblages, and sites situated at latitudes $>35^{\circ} \mathrm{N}$ (i.e., Sites 106 and 604), where colder-water species suddenly tend to become predominant. I suggest that this area is the contact zone where the influence of the (warm) Gulf Stream ceased and that of the (cold) Labrador current began.

4. Among all the sites reviewed, Hole 604 , through its microfaunal assemblages, seems most clearly to reflect major events or crises, most of which may correspond to global climatic changes or at least to major alternating polar glacial-interglacial cycles (Table 2).

5 . The first major event reflected occurred during the late Miocene (Core 604-25) at a time slightly earlier than $5.2 \mathrm{Ma}$. It is not clear whether this event directly reflects a real global climatic change (Southern Hemisphere glaciation ?) or is caused by a shallowing of the CCD, said to be worldwide in late Miocene times (Berggren, 1982).

6. Several oscillations of possible climatic origin are seen in the early to middle Pliocene, including a short warmer period at about $4.8 \mathrm{Ma}$, then a colder interval starting at $4.7 \mathrm{Ma}$ and culminating at about $3.9 \mathrm{Ma}$, and, finally, an apparent warming between 3.8 and 3.2 to $3.1 \mathrm{Ma}$. 
Table 1. Variations in the thickness (in meters) of upper Miocene to Quaternary deposits drilled along the east American margin in the northwest Atlantic.

\begin{tabular}{|c|c|c|c|c|c|c|c|c|c|c|c|c|c|c|}
\hline & $\underset{\text { B-2 }}{\operatorname{CosT}}$ No. & $\underset{\text { B-3 }}{\operatorname{CosT}}$ No. & Site 612 & Site 108 & Site 605 & Site 604 & Site 613 & Site 106 & Site 603 & Site 105 & Site 387 & Site 533 & Site 102 & Site 103 \\
\hline Quaternary & 120 & 150 & $\gg 40$ & & 200 & 150 & $\geq 180$ & 350 & Len & 40 & 40 & 150 & 220 & \\
\hline Pliocene & 60 & 60 & $\geq 50$ & & & 60 & $\geq 80$ & 150 & 350 & $\geq 60$ & & $\gg 250$ & 350 & $\frac{22}{40}$ \\
\hline upper Miocene & 140 & 120 & $\geq 50$ & & 18 & $?$ & 10 & 150 & & & & & & 300 \\
\hline
\end{tabular}

Note: See Init. Repts. DSDP for Legs 11, 44, 76; Poag, 1980; Poag, Watts, et al., pers. comm., 1984.

Table 2. Main events and crises delineated in Hole 604, with causal factors involved.

\begin{tabular}{|c|c|c|c|c|c|c|c|c|c|}
\hline $\begin{array}{l}\text { Core } \\
\text { no. }\end{array}$ & $\begin{array}{l}\text { Events } \\
(\mathrm{Ma})\end{array}$ & $\begin{array}{l}\text { Calcite } \\
\text { dissolution }\end{array}$ & $\begin{array}{l}\text { Hydrodynamic } \\
\text { winnowing }\end{array}$ & $\begin{array}{c}\text { Planktonic } \\
\text { productivity } \\
\text { high }\end{array}$ & $\begin{array}{l}\text { Sedimentation } \\
\text { rate }\end{array}$ & Erosion & Reworking & Climate & Interpretation \\
\hline 1 (top) & Recent & & $\mathrm{X}$ & $\mathrm{X}$ & High & & & Warm & \\
\hline 2 & 0.15 & $\mathrm{X}$ & & & High & $\mathrm{X}$ & X (Eocene) & Cold & \\
\hline $10-11$ & $1.38-1.48$ & $\mathrm{X}$ & & & Very high & $\mathrm{X}$ & X (Miocene) & Cold & $\begin{array}{l}\text { Mid-Pleistocene intensifi- } \\
\text { cation of Northern } \\
\text { Hemisphere glaciation }\end{array}$ \\
\hline 12 & 1.56 & & $\mathrm{X}$ & & Very high & & & Cold & \\
\hline 16 & 1.7 & $?$ & & & Very high & & & Warm & \\
\hline 19 & 3.0 & $\mathrm{X}$ & & & Low & & & Cold & $\begin{array}{l}\text { Inception of Northern } \\
\text { Hemisphere glaciation } \\
\text { (precursor?) }\end{array}$ \\
\hline 21 & 3.9 & $\mathrm{X}$ & & & Low & & & Cold & \\
\hline 23 & 4.8 & & & $\mathrm{X}$ & Intermediate & & & Warm & \\
\hline 25 & $\geq 5.2$ & $\mathrm{X}$ & & & Intermediate & & & Cold? & $\begin{array}{l}\text { Southern Hemisphere } \\
\text { glaciation? }\end{array}$ \\
\hline
\end{tabular}

7. An abrupt change occurs in Core $604-19$, dated at about 3.0 Ma (boundary between Zones PL3 and PL4). Surprisingly, no evidence of a major cold event at about 2.5-2.2 Ma, which, several authors have claimed, represents the inception of Northern Hemisphere glaciation (Backman, 1979; Mörner and Backman, 1980, Shackleton and Hall, 1984), was found either at Site 604 or at Sites 603 (Ma'alouleh and Moullade, this volume) and 533 (Moullade, 1983). On the contrary, the event at about 3.0 Ma was clearly depicted at all three sites by using quantitative micropaleontological methods. Further, an abrupt isotopic shift is recorded at Site 604 (Ganssen, this volume) at $3.0 \mathrm{Ma}$, and nothing significant around 2.4-2.2 Ma.

8. The variations in composition of the planktonic foraminiferal content made it possible to fairly clearly delineate large-scale alternating glacial-interglacial cycles in the Quaternary at Site 604 and also to attempt to delineate the climatic zonation established in the tropical realm by Ericson and Wollin (1968). This preliminary scheme, based only on quantitative micropaleontological methods, would be greatly improved by direct comparison with the results of isotopic measurements. However, large parts of the Pleistocene history could not be isotopically documented at Site 604 because of sampling intervals that were too widely spaced and also because of postulated sedimentary redeposition processes (see Ganssen, this volume).

9. Globally, the quantitative foraminiferal (planktonic species diversity; percentage of planktonic foraminifers; Figs. 8-9) and mineralogic (Fig. 5) parameters concur in depicting accentuated temperature declines in the later of the Pleistocene (Zones R to W), compared to the earlier. This probably corresponds with a middle/late Pleistocene intensification of Northern Hemisphere glaciation, already noted in the North Atlantic by Berggren (1982) and in the Gulf of Mexico by Prell (1982).

\section{ACKNOWLEDGMENTS}

I thank DSDP for inviting me to participate in Legs 76 and 93 of the Project, and Dr. William A. Berggren (Woods Hole Oceanographic Institution) and Dr. Dean A. Dunn (The University of Southern Mississippi at Hattiesburg) for reviewing the manuscript.

Financial support for this study was provided by the Centre National de la Recherche Scientifique under Grants ATP "GéologieGéophysique des Océans" n³18/366 and "Jeune Equipe" nº 333.

\section{REFERENCES}

Backman, J., 1979. Pliocene biostratigraphy of DSDP Sites 111 and 116 from the North Atlantic Ocean and the age of Northern Hemisphere glaciation. Stockholm Contrib. Geol., 32:115-137.

Bé, A. W. H., 1977. An ecological, zoogeographic and taxonomic review of Recent planktonic Foraminifera. In Ramsay, A. T. S. (Ed.), Oceanic Micropaleontology (Vol. 1): London (Academic Press), $1-100$.

Benson, W. E., Sheridan, R. E., et al., 1978. Init. Repts. DSDP, 44: Washington (U.S. Govt. Printing Office).

Blanc-Vernet, L., 1983. Benthic foraminifers of Site 533, Leg 76 of the Deep Sea Drilling Project-faunal variations during the Pliocene and Pleistocene on the Blake Outer Ridge (western North Atlantic). In Sheridan, R. E., Gradstein, F. M., et al., Init. Repts. DSDP, 76: Washington (U.S. Govt. Printing Office), 497-509.

Berggren, W. A., 1977. Late Neogene planktonic foraminiferal biostratigraphy of the Rio Grande Rise (South Atlantic). Mar. Micropaleontol., 2:265-313.

1982. Neogene planktonic foraminiferal biostratigraphy and biogeography: Atlantic, Mediterranean and Indo-Pacific regions. In Tsuchi, R. (Ed.), Pacific Neogene Datum Planes. Int. Geol. Correl. Progr., IGCP Project 114, Univ. Tokyo Press. 
Berggren, W. A., Aubry, M. P., and Hamilton, N., 1983. Neogene magnetobiostratigraphy of Deep Sea Drilling Project Site 516 (Rio Grande Rise, South Atlantic). In Barker, P. F., Carlson, R. L., Johnson, D. A., et al., Init. Repts. DSDP, 72: Washington (U.S. Govt. Printing Office), 675-713.

Briskin, M., and Berggren, W. A., 1975. Pleistocene stratigraphy and quantitative paleoceanography of tropical North Atlantic core V16205. In Saito, T., and Burckle, L. H. (Eds.), Late Neogene Epoch Boundaries (Vol. 1): New York (American Museum Natural History), 167-198.

Ericson, D. B., and Wollin, G., 1968. Pleistocene climates and chronology in deep-sea sediments. Science, 162(3859):1227-1234.

Gibson, T. G., and Buzas, M. A., 1973. Species diversity: Patterns in modern and Miocene foraminifera of the eastern margin of North America. Geol. Soc. Am. Bull., 84:217-238.

Hollister, C. D., Ewing, J. I., et al., 1972. Init. Repts. DSDP, 11: Washington (U.S. Govt. Printing Office).

Kennett, J. P., and Srinivasan, M. S., 1983. Neogene Planktonic Foraminifera: A Phylogenetic Atlas. Stroudsburg, PA (Hutchinson Ross).

Mörner, N. A., and Backman, J., 1980. Pliocene stratigraphy and paleoclimatology in Europe in relation to global paleoceanographic changes and the initiation of glaciations. 26th Int. Geol. Congr., Paris, Abstr. (Vol. 2), 676.

Moullade, M., 1983. Upper Neogene and Quaternary planktonic foraminifers from the Blake Outer Ridge and Blake-Bahama Basin
(Western North Atlantic), Deep Sea Drilling Project Leg 76, Sites 533 and 534. In Sheridan, R. E., Gradstein, F. M., et al., Init. Repts. DSDP, 76: Washington (U.S. Govt. Printing Office), 511535.

Poag, C. W., 1972. Neogene planktonic foraminiferal biostratigraphy of the Western North Atlantic: Deep Sea Drilling Project Leg 11. In Hollister, C. D., Ewing, J. I., et al., Init. Repts. DSDP, 11: Washington (U.S. Govt. Printing Office), 483-543.

1980. Foraminiferal stratigraphy, paleoenvironments, and depositional cycles in the outer Baltimore Canyon Trough. In Scholle, P. A. (Ed.), Geological Studies of the COST No B-3 Well, United States Mid-Atlantic Continental Slope Area. U.S. Geol. Surv. Circular 833:44-65.

Prell, W. L., 1982. Oxygen and carbon isotope stratigraphy for the Quaternary of Hole 502B: evidence for two modes of isotopic variability. In Prell, W. L., Gardner, J. V., et al., Init. Repts. DSDP, 68: Washington (U.S. Govt. Printing Office), 455-464.

Shackleton, N. J., and Hall, M. A., 1984. Oxygen and carbon isotope stratigraphy of Deep Sea Drilling Project Hole 552A: Plio-Pleistocene glacial history. In Roberts, D. G., Schnitker, D., et al., Init. Repts. DSDP, 81: Washington (U.S. Govt. Printing Office), 599609.

Date of Initial Receipt: 29 January 1985 Date of Acceptance: 11 May 1985 